\title{
Terrestrial trophic dynamics in the Canadian Arctic
}

\author{
Charles J . Krebs, Kjell Danell, Anders Angerbjörn, J ep Agrell, \\ Dominique Berteaux, Kari Anne Bråthen, Öje Danell, Sam Erlinge, \\ Vadim Fedorov, Karl Fredga, J oakim Hjältén, Göran Högstedt, \\ Ingibjörg S. J ónsdóttir, Alice J . Kenney, Nils Kjellén, Torgny Nordin, \\ Heikki Roininen, Mikael Svensson, Magnus Tannerfeldt, and Christer Wiklund
}

\begin{abstract}
The Swedish Tundra Northwest Expedition of 1999 visited 17 sites throughout the Canadian Arctic. At 12 sites that were intensively sampled we estimated the standing crop of plants and the densities of herbivores and predators with an array of trapping, visual surveys, and faecal-pellet transects. We developed a trophic-balance model using ECOPATH to integrate these observations and determine the fate of primary and secondary production in these tundra ecosystems, which spanned an 8-fold range of standing crop of plants. We estimated that about $13 \%$ of net primary production was consumed by herbivores, while over $70 \%$ of small-herbivore production was estimated to flow to predators. Only $9 \%$ of large-herbivore production was consumed by predators. Organization of Canadian Arctic ecosystems appears to be more top-down than bottom-up. Net primary production does not seem to be herbivore-limited at any site. This is the first attempt to integrate trophic dynamics over the entire Canadian Arctic.
\end{abstract}

Résumé : En 1999, l'Expédition suédoise de la toundra du nord-ouest à échantillonné 17 sites à travers l'arctique canadien. Nous avons utilisé différentes méthodes de trappage, des recensements visuels et des transects de décomptes de fèces pour estimer la biomasse végétale, ainsi que les densités des herbivores et des prédateurs aux 12 sites inventoriés plus en détail. Nous avons développé un modèle d'équilibre trophique à l'aide d'ECOPATH pour intégrer ces observations et déterminer le sort des productions primaire et secondaire de ces écosystèmes de toundra, entre lequels la biomasse végétale varie par un facteur de 8 . Nous estimons qu'environ $13 \%$ de la production primaire nette est consommée par les herbivores, tandis que plus de $70 \%$ de la production des petits mammifères est consommée par les prédateurs. Seulement $9 \%$ de la production des grands herbivores est consommée par les prédateurs. Ces écosystèmes semblent façonnés plus par les effets trophiques descendants (top-down) que par les effects trophiques ascendants (bottom-up). La production primaire nette de ces sites ne semble pas limitée par les herbivores. Notre étude constitue la première tentative pour intégrer les la dynamique trophique sur l'ensemble de l'arctique canadien.

\section{Introduction}

The arctic tundra, the area north of the treeline, occupies nearly $10 \%$ of the land area of the earth, and there is considerable interest in the response of this biota to global change.
To understand change in any of the biomes we must have an established baseline, and while a considerable amount of ecological research has been done in the polar regions of the arctic, there is as yet little synthesis. The Swedish Tundra Northwest Expedition to the Canadian Arctic in 1999 has

Received 12 August 2002. Accepted 1 April 2003. Published on the NRC Research Press Web site at http://cjz.nrc.ca on 30 May 2003.

C.J. Krebs ${ }^{1}$ and A.J. Kenney. Department of Zoology, The University of British Columbia, 6270 University Boulevard, Vancouver, BC V6T 1Z4, Canada.

K. Danell and J. Hjältén. Department of Animal Ecology, Swedish University of Agricultural Sciences, SE-901 83 Umeå, Sweden. A. Angerbjörn and M. Tannerfeldt. Department of Zoology, Stockholm University, SE-106 91 Stockholm, Sweden.

J. Agrell, S. Erlinge, N. Kjellén, and M. Svensson. Department of Animal Ecology, Lund University, SE-223 62 Lund, Sweden.

D. Berteaux. Département de biologie, Université du Québec à Rimouski, 300 allée des Ursulines, Rimouski, QC G5L 3A1,

Canada.

K.A. Bråthen. Institute of Biology, University of Troms $\varnothing$, N-9037 Tromsø, Norway.

Ö. Danell. Department of Animal Breeding and Genetics, Swedish University of Agricultural Sciences, SE-750 07 Uppsala,

Sweden.

V. Fedorov and K. Fredga. Department of Conservation Biology and Genetics, Uppsala University, SE-752 36 Uppsala, Sweden.

G. Högstedt. Department of Zoology, Zoological Institute, University of Bergen, N-5007 Bergen, Norway.

I.S. Jónsdóttir. The University Courses at Svalbard, P.O. Box 156, N-9171 Longyearbyen, Norway.

T. Nordin. Department of Philosophy, Göteborg University, SE-405 30 Göteborg, Sweden.

H. Roininen. Department of Biology, University of Joensuu, P.O. Box 111, FI-80101 Joensuu, Finland.

C. Wiklund. Department of Zoology, Göteborg University, SE-405 30 Göteborg, Sweden.

${ }^{1}$ Corresponding author (e-mail: krebs@zoology.ubc.ca). 
provided us with an opportunity to begin a synthesis of polar plant and animal communities with a view to understanding the factors that drive the dynamics of these ecosystems. During the summer of 1999 the Swedish Tundra Northwest Expedition visited 17 sites $^{2}$ across a $3000 \mathrm{~km}$ long east-west transect from Baffin Island to the Yukon and a $2000 \mathrm{~km}$ long north-south transect from the Ungava Peninsula to Ellef Ringnes Island.

The purpose of this paper is to describe the trophic dynamics of the Canadian Arctic using the data collected from these sites (Fig. 1). In particular we have estimated the standing crop of vegetation, herbivores, and carnivores from 12 of these sites, and the food-chain structure of these tundra communities. We attempt to estimate the productivity of each of these trophic components, and ultimately to test whether the organization of these tundra communities is predominantly top-down or more bottom-up (Power 1992). We do not think we can fully answer this question with our descriptive data, but we suggest results that can be used to form a set of hypotheses for further investigations. Our results are relevant to the question raised by $\mathrm{Cyr}$ and Pace (1993) about the magnitude of herbivory in different ecosystems, and the questions about food webs raised by Chase (2000), who reflects on the few data available to make direct comparisons among ecosystem types.

\section{Methods}

Various methods were used, but we standardized our data collecting in order to use the same methods at each site. We summarize these methods by trophic level and methods used.

\section{Plant sampling}

\section{Estimation of the standing crop of vascular plant}

Plant sampling was carried out on two scales. Within the intensive study area we estimated the standing crop of vegetation by estimating plant cover in two hundred $1-\mathrm{m}^{2}$ quadrats spread systematically along lemming sampling lines. Visual estimates of cover were made for the following plant groups: Dryas, Salix, Carex, Eriophorum, grasses, mosses, Saxifraga, and other herbs. These groups represent different categories of herbivore forage. We did not sample plant standing crop adequately at sites $1-5$, so plant biomass was not available for these sites. We used these small-scale plots to estimate plant biomass on a larger scale of $1-2 \mathrm{~km}^{2}$, as discussed below.

At five different sites we estimated cover and clipped all vegetation (except mosses and lichens) and removed all dead material on a total of 42 quadrats of $0.25 \mathrm{~m}^{2}$ to calibrate our cover estimates with standing crop biomass. For Salix we clipped leaves only. We did not clip Saxifraga or other herbs. Clipped samples were dried at $40^{\circ} \mathrm{C}$ for $48 \mathrm{~h}$. We found that the cover estimates correlated well with biomass (Table 1). This agrees with Röttgermann et al. (2000), who showed that the relationship between cover and biomass is good in low, open vegetation and that calibration of different growth forms is sufficient to obtain acceptable accuracy in estimation of species' biomass. Our regressions in Table 1 agree closely with those reported in Parker (1975).

We report all our data on the spatial scale of the local areas that we covered intensively. These intensive-study areas covered $1-2 \mathrm{~km}^{2}$ and were selected to be the relatively more productive parts of the local region. We did not try to extrapolate our data to a larger scale because we did not have all the parameters measured at larger scales. We mapped the vegetation types on the intensive-study area by means of digital aerial photographs obtained from helicopter transects. We classified vegetation types as described in Table 2. Because we had extensive ground truthing within the intensivestudy area, we could recognize these communities and map them using the aerial photographs over areas of $1-2 \mathrm{~km}^{2}$ (average $1.25 \mathrm{~km}^{2}$ ). There was a high correlation between the proportions of vegetation types determined by aerialphotograph mapping and by the systematic ground surveys made along linear transects of lemming trap lines $(n=56$, $r=0.86$ ), so we have used the systematic ground sample as our measure of vegetation-type coverage at all sites.

We used the following equation to estimate the average standing crop of a particular forage group, $x$, in $0.25 \mathrm{~m}^{2}$ of a local area:

$$
\begin{aligned}
\text { Standing crop } x=\sum_{h}\left(\begin{array}{l}
\text { proportion } \\
\text { of local area } \\
\text { occupied by } \\
\text { this vegetation } \\
\text { type }
\end{array}\right) \\
\\
\times\left(\begin{array}{l}
\text { percent-cover } \\
\text { estimate } \\
\text { for species } \\
\text { this vegetation } \\
\text { type }
\end{array}\right)\left(\begin{array}{l}
\text { slope of } \\
\text { regression } \\
\text { for species }
\end{array}\right)
\end{aligned}
$$

and the summation is taken across all vegetation types $(h)$. The critical regressions needed for standing-crop estimates are the regressions of biomass in $0.25 \mathrm{~m}^{2}$ against percent cover. Table 1 gives these regressions for each forage group. For Saxifraga and other herbs we used the regression slope estimated for Dryas. For mosses we used the regression slope estimated by Bliss et al. (1984). We are unable to determine the error limits of these standing-crop estimates because we have no way of measuring the precision of the first two variables in eq. 1.

\section{Phenological corrections}

Estimates of standing crop depend on phenology, and because there was a considerable phenological change during the expedition a correction was needed. Sedges are well suited for such correction, as their leaves stay attached for some years after they wither and thus allow a comparison of the length of the longest leaf from the previous year with the longest leaf from the current year. For these measurements we always used the same developmental stage, "old vegeta-

\footnotetext{
${ }^{2}$ We could not adequately sample sites $1-5$ for vegetation.
} 
Fig. 1. Map of the Canadian Arctic showing the locations of the sites visited by the Swedish Tundra Northwest Expedition of 1999 (red circles) and existing weather stations (black squares). A total of 17 sites were visited but data from sites 1-5 are incomplete for plants, so detailed data on all trophic levels are available from only 12 sites.

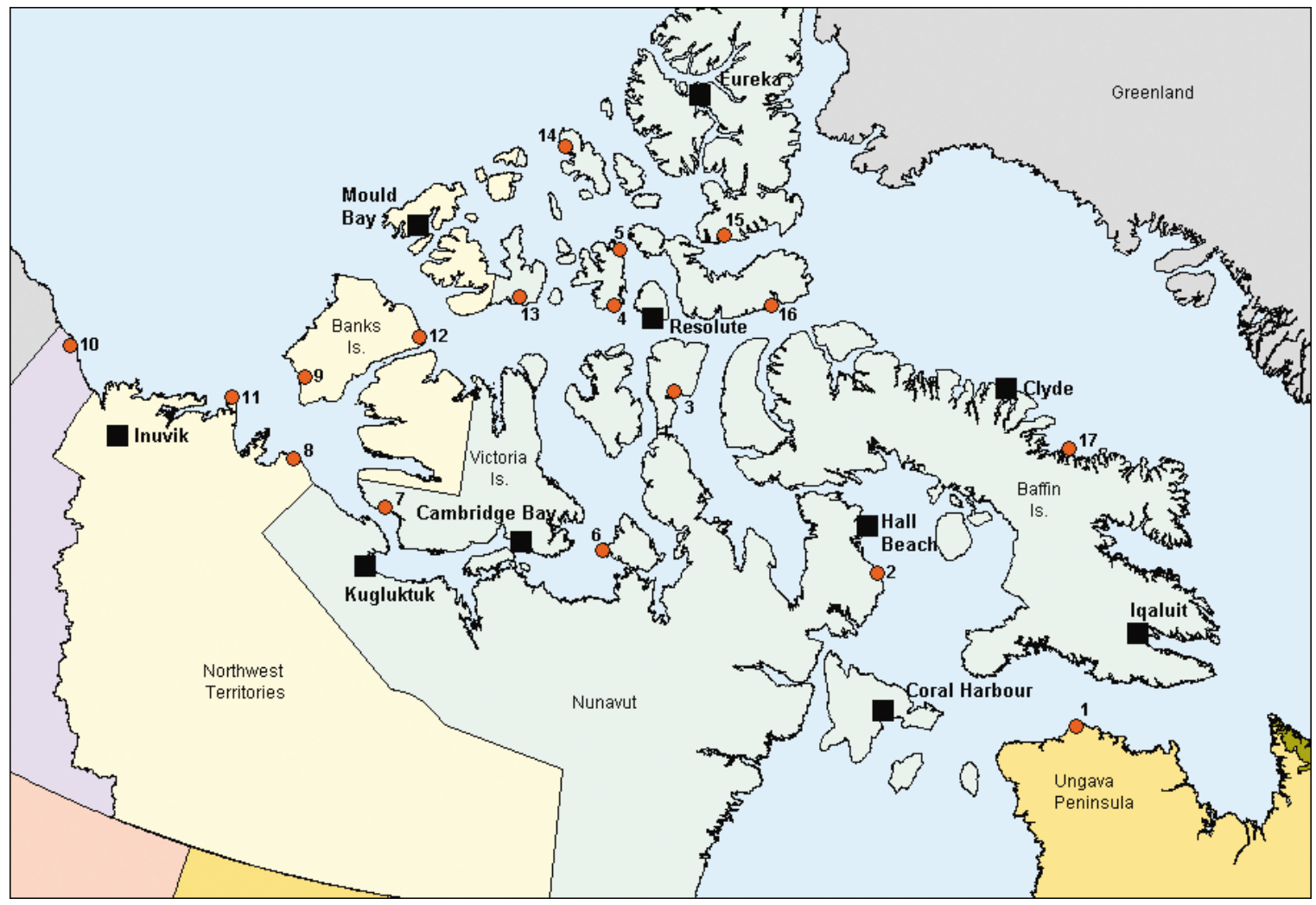

Table 1. Regression estimates for clip plots for estimation of standing crop (biomass dry mass per $0.25 \mathrm{~m}^{2}(Y)$ versus visual cover estimates $(X)$; the $Y$ intercepts were assumed to be 0 for all regressions).

\begin{tabular}{|c|c|c|c|c|c|c|}
\hline & $\begin{array}{l}\text { Sample } \\
\text { size }\end{array}$ & Slope & SE slope & $\begin{array}{l}\text { Lower } 95 \% \\
\text { confidence } \\
\text { limits }\end{array}$ & $\begin{array}{l}\text { Upper } 95 \% \\
\text { confidence } \\
\text { limits }\end{array}$ & $r^{2}$ \\
\hline Carex & 28 & 0.2608 & 0.01752 & 0.2249 & 0.2967 & 0.89 \\
\hline Dryas & 24 & 0.2896 & 0.02535 & 0.2372 & 0.3420 & 0.85 \\
\hline Eriophorum & 11 & 0.1897 & 0.02229 & 0.1400 & 0.2393 & 0.88 \\
\hline Grasses & 15 & 0.2764 & 0.04527 & 0.1793 & 0.3735 & 0.73 \\
\hline Willow leaves & 27 & 0.1800 & 0.00720 & 0.1652 & 0.1948 & 0.96 \\
\hline
\end{tabular}

tive ramets", which are ramets that produced green leaves last year and did not flower this year.

At all sites except 15 we used one or more species of Carex and Eriophorum. The Carex species was either C. stans or belonged to the $C$. bigelowii species complex (Murray 1994), and the Eriophorum species was E. angustifolium. The populations used in the study were on mesic to dry soil on either level terrain or gentle southfacing slopes. Within a $30 \times 6 \mathrm{~m}^{2}$ grid at each site at least ten $50 \times 50 \mathrm{~cm}$ plots were sampled. Plots were positioned every third metre along the long side of the grid. Every plot was divided into four quadrats. In each quadrat the Carex and Eriophorum ramets closest to the center were chosen for leaf-length measurements and the plot means were calculated for each species. The vegetative phenology of a site is reflected by the average difference between the two leaf lengths. A correction factor, $P_{h}$, for phenological differences in biomass between sites was calculated for each site in the following way:

$$
P_{h}=[(\mathrm{PL})+(\mathrm{CL})] / 2(\mathrm{PL})
$$

where $P_{h}$ is the standardized phenology correction estimate, $\mathrm{PL}$ is the length of the longest leaf from the previous year, and $\mathrm{CL}$ is the length of the longest leaf from the current year. For these corrections we assume that growth during the previous year was identical with growth during the current season. By 7 August, when we reached site 11, the vegetative phenology for the season was complete and the standardized phenology index was 1.0. 
Table 2. Main plant community types in the tundra vegetation used in this study.

\begin{tabular}{|c|c|c|}
\hline Community type & $\begin{array}{l}\text { Vegetation } \\
\text { cover }\end{array}$ & Examples of dominating species \\
\hline Polar deserts & $\leq 2 \%$ & Draba spp., Papaver radicatum, Saxifraga spp., lichens \\
\hline Fellfields & $>2 \%,<50 \%$ & Cushion plants, mosses, and lichens \\
\hline \multicolumn{3}{|l|}{ Heaths } \\
\hline Shrub heath & $>50 \%$ & Betula nana, tall Salix spp. \\
\hline Dwarf-shrub heath & $>50 \%$ & Dryas integrifolia, Salix spp., Cassiope tetragona \\
\hline Cryptogam - herb heath, High Arctic & $>50 \%$ & Alopecurus alpinus, Luzula spp., Draba spp., Saxifraga spp., mosses, lichens \\
\hline \multicolumn{3}{|l|}{ Mesic meadows/tundras } \\
\hline Tussock tundra & $>50 \%$ & Eriophorum vaginatum, Carex spp. \\
\hline Mesic sedge meadow & $>50 \%$ & Carex spp., Eriophorum spp., grasses (Arctophila, Arcagrostis, Dupontia) \\
\hline \multicolumn{3}{|r|}{${ }^{2}$} \\
\hline Sedge-moss wetlands/mires & $>50 \%$ & Carex stans, Carex spp, Eriophorum angustifolium, Eriophorum scheuchzeri \\
\hline
\end{tabular}

\section{Plant productivity}

A key problem is how we can obtain estimates of plant production in arctic areas from short site visits. We could not measure plant productivity directly, so we must rely on other production data for our sites. We have used literature data on net primary production and production per unit biomass (P/B ratio) in Bliss (1977), Bliss and Svoboda (1984), Bliss et al. (1984), Komárková and Webber (1980), Muc (1977), Shaver and Chapin (1991), Svoboda (1977), Vitt and Pakarinen (1977), Webber (1978), Wein and Bliss (1974), and Wielgolaski et al. (1981) to convert our standing-crop estimates to primary-production estimates. To estimate ratios of net primary production to live phytomass $(P / B)$, along with $95 \%$ confidence limits, for three of the plant growth forms, herbs, woody plants, and graminoids, we used data from all these literature sources, while for mosses the $P / B$ ratio was estimated using total phytomass. Herbs, woody plants, graminoids, and mosses are the growth forms that make up the forage groups listed in Table 3. We were not able to gather enough published data to investigate whether the $P / B$ ratios varied among the vegetation zones of the Low and High Arctic or among vegetation types for the same forage group. Given the standing-crop estimates shown in Table 3, we applied the phenological correction indices given in Table 4 and the $P / B$ ratios listed in Table 5 to compute the estimated total net annual primary production for each site.

$$
\begin{aligned}
& \text { Net primary production } \\
& \qquad=\sum_{h}\left[(\text { standing crop })\left(\frac{P}{B}\right)\left(\frac{1}{P_{h}}\right)\right]
\end{aligned}
$$

where the standing crop is estimated from eq. 1 , the $P / B$ ratio is from Table 5 (production biomass ratios), $P_{h}$ is from eq. 2 (phenological correction factor), and the summation is taken over all the forage groups shown in Table 3 .

\section{Lemming sampling}

At each site we used three different methods to estimate lemming abundance: systematically placed snap traps, selectively placed snap traps, and counts of winter nests. First, we laid out 10 snap-trap lines of 20 stations each, with three traps per station and $15-\mathrm{m}$ spacing between stations. The snap traps were baited with peanut butter and raisins. Where possible we laid the lines out in parallel, $100 \mathrm{~m}$ apart, but in most areas suitable lemming habitat was so patchy that we used single lines. In general, trap lines were spread over 1$2 \mathrm{~km}^{2}$. We ran these traps for 24-48 $\mathrm{h}$, depending on the time available at each site.

To increase the sample size for demographic analyses, additional (20-40) snap traps were placed in patches with potential lemming activity. We have also included snap traps set for genetic analyses in places with indications of lemming activity (Fedorov et al. 1999). This resulted in an average of 164 extra trap-nights at each site (range $=48-331$, $\mathrm{SD}=63$ ). These traps were always set out at least $100 \mathrm{~m}$ from the trap lines to avoid interference with density estimates.

We also used lemming winter nests to provide an index of lemming densities over the previous winter, 1998-1999. We censused winter nests by line-transect techniques (Buckland et al. 1993), estimating perpendicular distances to nests from the transect line. We averaged $28 \mathrm{~km}$ of transects at each site (range $=4-58 \mathrm{~km}$ ) and found, on average, 19 winter nests per site (range $=1-48$ ). Winter nest densities were converted to spring lemming density by the following regression: density $($ number $/$ ha $)=0.0711($ nests $/$ ha $)+0.3046(\text { nests } / \text { ha })^{2}$ (C.J. Krebs, unpublished data).

\section{Faecal-pellet counts}

We estimated biomass of herbivores from densities of faecal pellets, persistence time of pellets, defecation rate, and body mass of each species. Pellet transects were performed at each site on all lemming snap-trap lines. Extra transects were done in special habitats if the trap lines were not representative of the study site. The total length of pellet transects performed per site averaged $4.7 \mathrm{~km}(\mathrm{SD}=2.9 \mathrm{~km})$ for muskoxen, $5.2 \mathrm{~km}(\mathrm{SD}=2.9 \mathrm{~km})$ for caribou, $4.7 \mathrm{~km}(\mathrm{SD}=$ $2.6 \mathrm{~km})$ for hares, $4.7 \mathrm{~km}(\mathrm{SD}=2.4 \mathrm{~km})$ for ptarmigan, and $4.2 \mathrm{~km}(\mathrm{SD}=2.7 \mathrm{~km})$ for geese. Pellet groups from muskoxen and caribou were counted, whereas individual faecal pellets of hares, ptarmigans, and geese were the units measured. The perpendicular distance from the line to the 
Table 3. Observed standing crop of major forage groups from sites 6-17 visited during summer 1999.

\begin{tabular}{|c|c|c|c|c|c|c|c|c|c|c|}
\hline \multirow[b]{2}{*}{$\begin{array}{l}\text { Site } \\
\text { No. }\end{array}$} & \multirow[b]{2}{*}{ Site name } & \multicolumn{9}{|c|}{ Standing crop $(\mathrm{kg} / \mathrm{ha})$} \\
\hline & & Dryas & Willows & Carex & Eriophorum & Grasses & Saxifraga & Herbs & $\begin{array}{l}\text { Total } \\
\text { vascular }\end{array}$ & Mosses \\
\hline 6 & King William Island & 274 & 46 & 154 & 2 & 0 & 23 & 2 & 501 & 1339 \\
\hline 7 & Wollaston Peninsula & 169 & 82 & 204 & 20 & 15 & 7 & 21 & 519 & 456 \\
\hline 8 & Amundsen Gulf south & 153 & 56 & 320 & 54 & 2 & 4 & 40 & 630 & 690 \\
\hline 9 & Banks Island south & 361 & 101 & 213 & 6 & 29 & 1 & 17 & 727 & 2000 \\
\hline 10 & North Yukon & 70 & 161 & 159 & 213 & 30 & 0 & 112 & 745 & 2617 \\
\hline 11 & Cape Bathurst & 115 & 21 & 411 & 74 & 51 & 0.3 & 4 & 676 & 2643 \\
\hline 12 & Banks Island north & 121 & 103 & 54 & 7 & 14 & 24 & 9 & 331 & 1575 \\
\hline 13 & Melville Island & 0.4 & 106 & 53 & 0.7 & 33 & 37 & 9 & 239 & 3627 \\
\hline 14 & Ellef Ringnes Island & 0 & 0 & 0 & 0 & 43 & 23 & 30 & 96 & 3453 \\
\hline 15 & Ellesmere Island south & 30 & 94 & 43 & 27 & 12 & 26 & 0.1 & 233 & 503 \\
\hline 16 & Devon Island south & 151 & 47 & 65 & 14 & 21 & 20 & 42 & 360 & 1054 \\
\hline 17 & Baffin Island & 30 & 73 & 112 & 4 & 4 & 0 & 158 & 381 & 1731 \\
\hline
\end{tabular}

Note: All masses are given as dry mass in kilograms per hectare of the local area.

Table 4. Phenological correction factors; mean proportion of the length of the current year's leaf to the length of the previous year's leaf of Carex spp. and Eriophorum angustifolium ( $\pm 95 \%$ confidence limits (CL), $n \geq 10$ ).

\begin{tabular}{|c|c|c|c|c|c|c|}
\hline \multirow{2}{*}{$\begin{array}{l}\text { Site } \\
\text { No. }\end{array}$} & \multirow[b]{2}{*}{ Site name } & \multicolumn{2}{|c|}{ Carex spp. } & \multicolumn{2}{|c|}{ E. angustifolium } & \multirow{2}{*}{$\begin{array}{l}\text { Correction } \\
\text { factor }\end{array}$} \\
\hline & & Mean & $\mathrm{CL}$ & Mean & $\mathrm{CL}$ & \\
\hline 6 & King William Island & 0.93 & \pm 0.02 & & & 0.93 \\
\hline 7 & Wollaston Peninsula & 1.03 & \pm 0.03 & 0.84 & \pm 0.04 & 0.93 \\
\hline 8 & Amundsen Gulf south & 1.03 & \pm 0.03 & 0.89 & \pm 0.02 & 0.96 \\
\hline 9 & Banks Island south & 1.03 & \pm 0.03 & 0.94 & \pm 0.06 & 0.99 \\
\hline 10 & North Yukon & 0.85 & \pm 0.03 & 0.88 & \pm 0.04 & 0.86 \\
\hline 11 & Cape Bathurst & 1.03 & \pm 0.04 & 1.13 & \pm 0.05 & 1.08 \\
\hline 12 & Banks Island north & 1.07 & \pm 0.04 & 1.06 & \pm 0.03 & 1.07 \\
\hline 13 & Melville Island & 1.04 & \pm 0.03 & 1.04 & \pm 0.06 & 1.04 \\
\hline 15 & Ellesmere Island & 1.04 & \pm 0.03 & & & 1.04 \\
\hline 16 & Devon Island & 1.07 & \pm 0.02 & 1.06 & \pm 0.10 & 1.07 \\
\hline 17 & Baffin Island & 1.04 & \pm 0.02 & & & 1.04 \\
\hline
\end{tabular}

Note: The correction factor was used to adjust the observed standing crops in Table 3 to full-season growth.

Table 5. Annual net primary production and production/biomass $(P / B)$ ratios for each forage group.

\begin{tabular}{|c|c|c|c|c|c|c|c|c|c|}
\hline Site No. & Site name & \multicolumn{8}{|c|}{ Net primary production } \\
\hline 6 & King William Island & 219 & 37 & 139 & 2 & 0.00 & 19 & 1 & 29 \\
\hline 8 & Amundsen Gulf south & 116 & 42 & 274 & 47 & 1 & 3 & 31 & 14 \\
\hline 9 & Banks Island south & 274 & 76 & 182 & 5 & 25 & 1 & 13 & 40 \\
\hline 10 & North Yukon & 56 & 128 & 144 & 192 & 28 & 0 & 93 & 56 \\
\hline 13 & Melville Island & 0.3 & 76 & 43 & 1 & 27 & 28 & 7 & 70 \\
\hline 14 & Ellef Ringnes Island & 0 & 0 & 0 & 0 & 35 & 17 & 23 & 66 \\
\hline 15 & Ellesmere Island south & 22 & 67 & 35 & 22 & 10 & 19 & 0.04 & 10 \\
\hline 16 & Devon Island south & 109 & 34 & 53 & 11 & 17 & 15 & 31 & 20 \\
\hline 17 & Baffin Island & 21 & 52 & 91 & 4 & 3 & 0 & 117 & 33 \\
\hline
\end{tabular}

Note: All production estimates are given as kilograms dry mass per hectare per year, corrected for growth phenology. 
point of initial sighting of each pellet or pellet group was recorded to the nearest decimetre. We estimated pellet density for each species using the program DISTANCE 3.5 (Thomas et al. 1998). Calculations were made using the defaults of the program, except that we discarded the largest $10 \%$ of distances and assumed that the observations followed a Poisson distribution (Buckland et al. 1993). Based on the admittedly arbitrary estimates of persistence times of pellets from Klein and Bay (1994), we assumed that pellets persisted for 1 year in the wetlands, 2 years in the mesic meadows/ tundras, 5 years in the heaths, and 10 years in the fellfields and polar deserts. We assumed that defecation rates were 12 pellet groups per day per individual for muskoxen (Neff 1968), 25 pellet groups per day per individual for caribou (based on unpublished data from A. Skarin), 208 pellets per day per individual for hares (based on data for mountain hares, Lepus timidus, reported by Flux 1970), 120 droppings per day per individual for ptarmigan (Höglund 1980), and 73 droppings per day per individual for geese (based on data for barnacle geese, Branta leucopsis, reported by Van der Wal and Loonen 1998). We assumed body mass to be $234 \mathrm{~kg}$ for muskoxen (Tener 1965), $118 \mathrm{~kg}$ for caribou (Banfield 1974), $4.6 \mathrm{~kg}$ for hares (Banfield 1974), $0.42 \mathrm{~kg}$ for ptarmigan (Dunning 1993), and $1.37 \mathrm{~kg}$ for geese (Dunning 1993).

We were unable to make any estimate of invertebrate biomass in these tundra plots. Our results are only for the endotherms in the tundra community.

\section{Predator sampling}

We censused predatory mammals and birds at each site visually. The study was made throughout the breeding period of all species. We surveyed by walking an area of $8-90 \mathrm{~km}^{2}$ at each of the sites, the exact area surveyed depending mainly on weather and visibility. We used binoculars to spot mammals, birds, and nests or dens. For all mammal and bird species except passerines and waders, we counted all individuals, and for the predator species we also investigated breeding attempts, counted young, and noted nest or den positions. Fox dens were studied in detail. For avian lemming predators, records were taken on number of birds, number of pairs of mated birds, and number of nests. Birds that displayed territorial or breeding behaviour were classified as mated birds.

We collected prey remains, bird pellets, and fox scats for diet analyses. In total, we surveyed $758 \mathrm{~km}^{2}$ by walking. Furthermore, we carried out aerial counts of birds and large mammals on helicopter transects. These transects were 40$118 \mathrm{~km}$ long and were performed at 15 sites.

We collected arctic fox scats at eight sites. Fresh scats were separated from older scats by appearance. Older scats are dry and weathered or overgrown by recent vegetation. Fresh and old scats contained similar proportions of migrating birds, indicating that the scats were from summers only, making age separation easier. We ignored scats that were 2 years or older, as determined by extensive weathering, i.e., generally white, brittle, and overgrown with vegetation from previous seasons. Collections were made on dens and while performing predator surveys. Fresh scats were mostly collected on breeding dens. All collections were made between 1 and 29 July. In total, 133 fresh and 375 old scats were analysed. The maximum number of scats collected from each den or defecation site was 20 for fresh scats and 10 for old scats.

Scats were dried at $110^{\circ} \mathrm{C}$ and prey remains were identified using reference material. We fragmented individual scats by hand under a magnifying glass and estimated the proportions of fur, feathers, eggshells, insects, and vegetation by volume in the compacted dry scat. Frequency of occurrence is a common way to present results of diet analyses, but it does not take into account the proportions of different prey categories. Therefore, we converted the data into "whole-scat equivalents" (WSEs), as described by Angerbjörn et al. (1999). If scats were small or fragmented, we combined them so that the analysed volume in each sample was approximately that of one medium-sized scat. Thus, we could determine how many whole scats each category corresponded to. For instance, if we had one scat containing $30 \%$ bird (feathers) and $70 \%$ lemming (fur) and another scat containing $70 \%$ bird and $30 \%$ lemming, these were regarded as equivalent to one scat containing only lemming and one scat with only bird. The total number of scats, i.e., sample size, thus remained the same. As there are no conversion factors for the arctic fox diet, we had to assume that the proportion of remains of a prey species in the scats is a fair representation of its proportion in the diet.

The number of teeth from different rodent species in red fox scats is proportional to the ingested proportions of the species (Lockie 1959). We assumed this to be true also for arctic foxes, and when we found teeth from more than one rodent species in a scat, we used the number of teeth from each species to determine their relative proportions. When there were no teeth, the fur was classified as unidentified rodent (7\% WSE in fresh scats, 25\% WSE in old scats). For each site, that class of remains was divided into Lemmus and Dicrostonyx classes in the same proportions as the remains identified to species. We determined bird remains to order, using the keys of Brom (1986) and Day (1996). No attempt was made to further classify eggshells, insects, or plant material and we did not include microscopic fragments in the analysis. We found no identifiable remains of voles or arctic ground squirrels in the arctic fox scats. Sample sizes for fresh scats were adequate at only three sites. In the case of old scats, 25-50 were analysed from each site.

Ermine presence was noted from ermine winter nests. Estimates of ermine density are very difficult to obtain, and we used those given in Oksanen et al. (1999) for their highland site, which is most similar to our tundra-vegetation sites.

Wolf sign was noted at three sites, but since wolves range widely relative to our study areas, we have used wolf densities reported in the literature for the Canadian Arctic (Van Zyll de Jong and Carbyn 1999). Because there are few detailed data from different regions of the Arctic, we have used a uniform density of 0.001 wolves $/ \mathrm{km}^{2}$ for all sites except Banks Island, where the density is $0.003 / \mathrm{km}^{2}(\mathrm{~N}$. Larter, personal communication).

\section{Results}

Figure 2 shows the food web in the tundra areas sampled in this study. Not all species were present at all sites (Table 6). We do not have data on passerine birds, insects, fungi, or wide-ranging predators like the wolverine and griz- 
Fig. 2. A generalized food web for terrestrial tundra areas of the Canadian Arctic. Not all species occurred at all sites (see Table 6). We do not have data for the shaded compartments. Items that compose less than $5 \%$ of the diet are not connected.

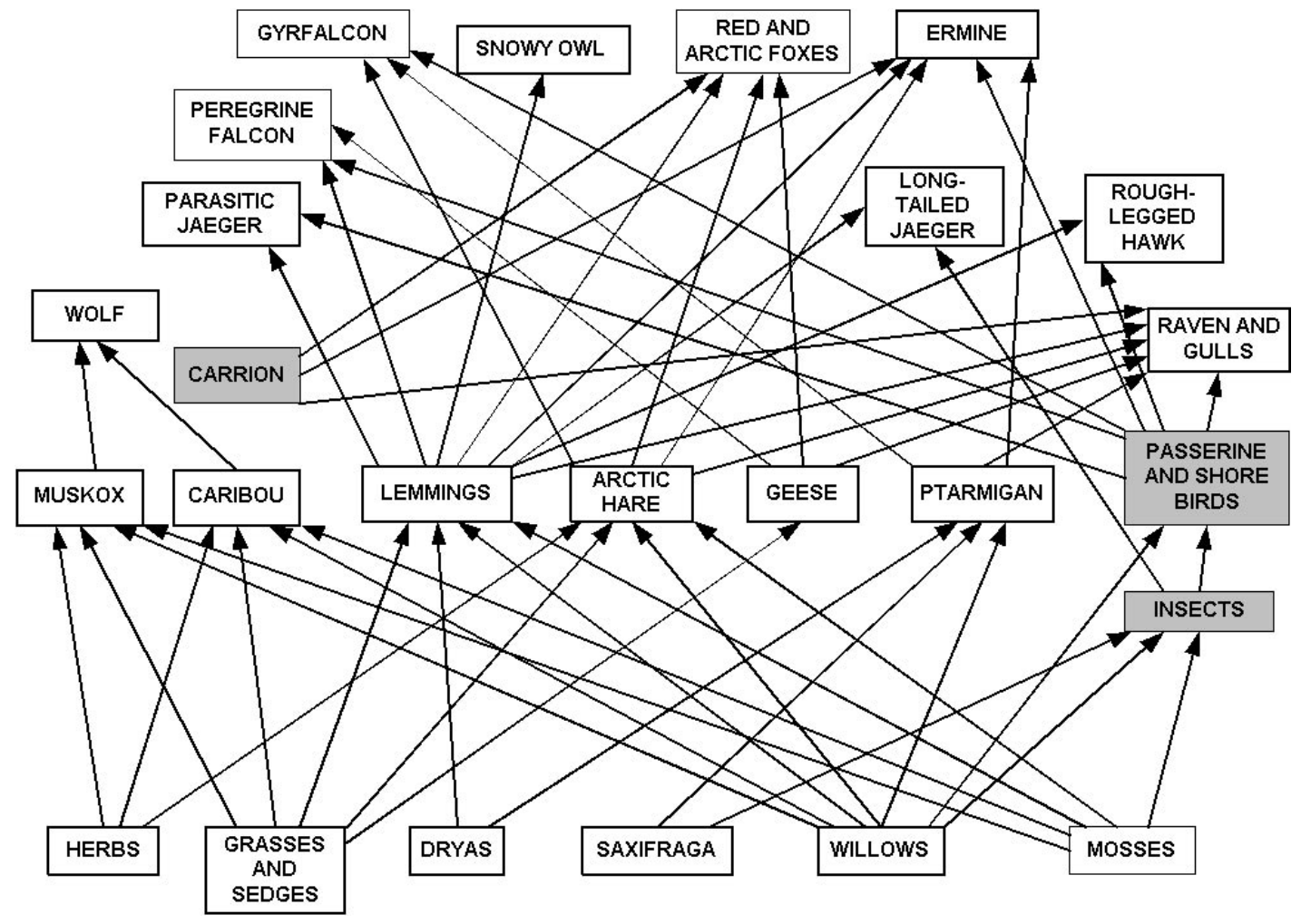

zly bear. Some species, like the arctic ground squirrel and tundra vole, are present only at the mainland sites and absent in the Arctic islands. We will now try to analyse the terrestrial arctic food web to determine the patterns of flow in productivity that occur within these arctic sites.

\section{Plant dynamics}

\section{Standing-crop estimates}

The standing-crop estimates for the sites visited are given in Table 3. Two main patterns are evident. Standing crop varied 8-fold over the 12 sites analysed, and in particular species-groups the range is even greater. The largest standing biomass of vascular plants was found in the western Arctic sites and the largest standing crop of mosses occurred at the High Arctic sites Melville Island and Ellef Ringnes Island.

Two qualifications must be made concerning these estimates of standing crop. We have not attempted to estimate lichen biomass, which can be significant at some of the sites. Second, we think that the biomass at site 10 in north Yukon is underestimated because the vegetation at this site was not low and open (Chiarucci et al. 1999). We were not able to clip quadrats at site 10 . Although we estimated average plant height for sedges and grasses at the five sites where we clipped quadrats, height never was a significant variable in our regressions to estimate standing crop at these sites dominated by low growth. Sedges were particularly luxuriant at site 10, and at this site and others in the Low Arctic we suspect that height and cover might both be important predictive variables for estimating standing crop.

\section{Plant productivity}

Net primary production of vascular plants ranged 9-fold across these sites, while moss production varied 7-fold (Table 5). Figure 3 shows that estimated net primary productivity of vascular plants fell dramatically with latitude. In our data there was a high correlation (Fig. 4) between standing crop of vascular plants and net primary productivity of vascular plants, which resulted from a limited range of $P / B$ ratios for arctic plants (Table 5).

\section{Herbivore dynamics}

\section{Lemming and vole populations}

We estimated over-winter density of lemmings from winter nest censuses at all sites except two (at which tussock tundra made it impossible to census winter nests) and estimated summer densities by snap trapping. Table 7 shows that with a few exceptions, lemming and vole populations were at low density in the summer of 1999 . Two sites ( 8 and 10) had very high populations of Microtus oeconomus, with a relatively moderate number of lemmings. These two sites contained the highest standing crop of small rodents, around $1.2 \mathrm{~kg} / \mathrm{ha}$.

\section{Other herbivores}

We used faecal-pellet densities to measure the presence of particular habitats and their usage by muskoxen, caribou, arctic hare, geese, and ptarmigan for each site. Pellet counts for larger herbivores average out population-density shifts and provide us with an average density of use. Table 7 gives density estimates for all the herbivores. We have no independent check of the validity of these estimates. Caribou and 
Table 6. Species or species-groups recorded at each of the 17 sites visited by the Swedish Tundra Northwest Expedition of 1999.

\begin{tabular}{|c|c|c|c|c|c|c|c|c|c|c|c|c|c|c|c|c|}
\hline \multirow[b]{2}{*}{ Species or species-group } & \multicolumn{16}{|c|}{ Site No. } \\
\hline & 1 & 2 & 3 & 4 & 6 & 7 & 8 & 9 & 10 & 11 & 12 & 13 & 14 & 15 & 16 & 17 \\
\hline \multicolumn{17}{|l|}{ Plants } \\
\hline Willows & $x$ & $x$ & $x$ & $\times$ & $x$ & $x$ & $\times$ & $x$ & $x$ & $\times$ & $\times$ & $x$ & & $x$ & $x$ & $x$ \\
\hline Grasses/sedges & $x$ & $x$ & $x$ & $x$ & $x$ & $x$ & $\times$ & $x$ & $x$ & $\times$ & $\times$ & $x$ & $x$ & $x$ & $x$ & $x$ \\
\hline Saxifraga & $x$ & $x$ & $x$ & $x$ & $x$ & $\times$ & $x$ & $x$ & & $x$ & $\times$ & $x$ & $x$ & $x$ & $x$ & \\
\hline \multicolumn{17}{|l|}{ Herbivores } \\
\hline Muskox & & & $x$ & $x$ & $x$ & $x$ & $x$ & $x$ & & & $x$ & $x$ & & $x$ & $x$ & \\
\hline Caribou & $x$ & $\times$ & & $x$ & & $\times$ & $x$ & $\times$ & $\times$ & $\times$ & $\times$ & $x$ & $\times$ & & $\times$ & \\
\hline Lemmings & $x$ & $x$ & $x$ & $x$ & $x$ & $\times$ & $x$ & $x$ & $x$ & $x$ & $\times$ & $x$ & $x$ & $x$ & $x$ & $x$ \\
\hline Arctic hare & & $x$ & $\times$ & $x$ & & $\times$ & $x$ & $\times$ & & & $\times$ & $x$ & & $\times$ & $x$ & $\times$ \\
\hline Foxes & $x$ & $x$ & & $x$ & $x$ & $x$ & & $x$ & $x$ & $x$ & $x$ & $x$ & $x$ & $x$ & $x$ & $x$ \\
\hline Raven & & $x$ & $x$ & & & $x$ & $\times$ & & $x$ & & & $x$ & & $x$ & & $x$ \\
\hline Glaucous gull & & $x$ & $x$ & $x$ & $x$ & $x$ & $x$ & $x$ & $x$ & $x$ & $\times$ & $x$ & $x$ & $x$ & $x$ & $x$ \\
\hline Rough-legged hawk & & & & & & $x$ & $\times$ & $x$ & $x$ & & $\times$ & & & & $x$ & \\
\hline Long-tailed jaeger & & $x$ & & $x$ & $\times$ & $\times$ & & $x$ & $\times$ & $\times$ & & & & & & \\
\hline Parasitic jaeger & & & & & $x$ & $x$ & & $x$ & $x$ & $\times$ & & & & $x$ & & \\
\hline Ermine & $x$ & & $\times$ & & & $\times$ & $\times$ & $x$ & & & & & & & $x$ & \\
\hline Snowy owl & & & & $x$ & $x$ & & & & $x$ & & & & & & $x$ & \\
\hline Peregrine falcon & $x$ & & $x$ & & & $x$ & $x$ & $x$ & $x$ & $x$ & $\times$ & & & $x$ & $x$ & \\
\hline Gyrfalcon & & & & & $x$ & & & & $x$ & & & $x$ & & & $x$ & \\
\hline Total & 3 & 4 & 4 & 4 & 5 & 8 & 5 & 7 & 9 & 5 & 4 & 3 & 2 & 5 & 7 & 3 \\
\hline
\end{tabular}

Note: Data from site 5 were incomplete and are not included here.

Fig. 3. Relationship between net primary production (NPP) of vascular plants and latitude for sites $6-17$ of the Swedish Tundra Northwest Expedition of 1999 (regression: NPP = $4212-$ 53.3(latitude), $r=-0.77$ ).

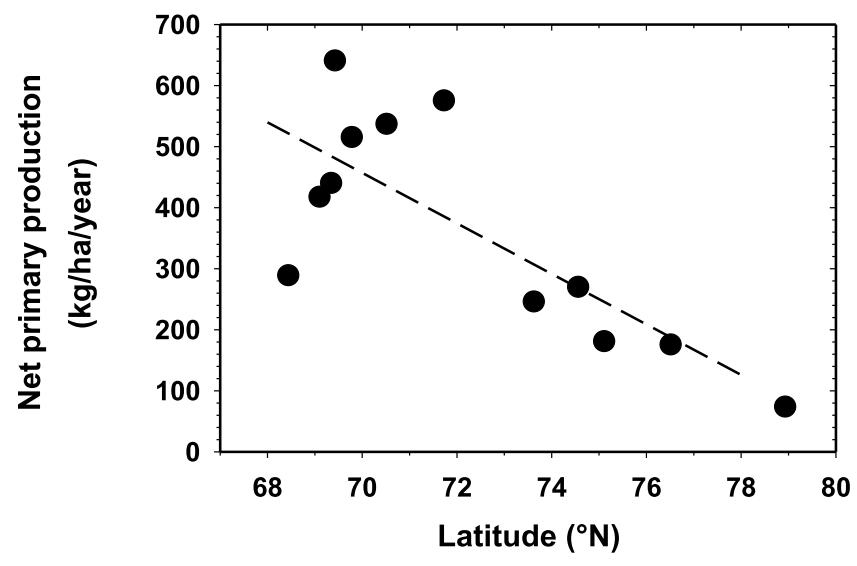

muskox densities have been estimated for some of the Arctic islands by Ferguson and Gauthier (1992), but these estimates apply to whole islands. Our study areas were selected to be of above-average productivity and it would not be valid to extrapolate our density estimates to the whole region. Our estimates of caribou and muskox densities are 13 and 18 times, respectively, those given for the whole islands by Ferguson and Gauthier (1992). There is a positive correlation
Fig. 4. Relationship between standing crop of vascular plants and net primary production of vascular plants at sites 6-17 of the Swedish Tundra Northwest Expedition of 1999 ( $r=0.99$, $n=12$ ).

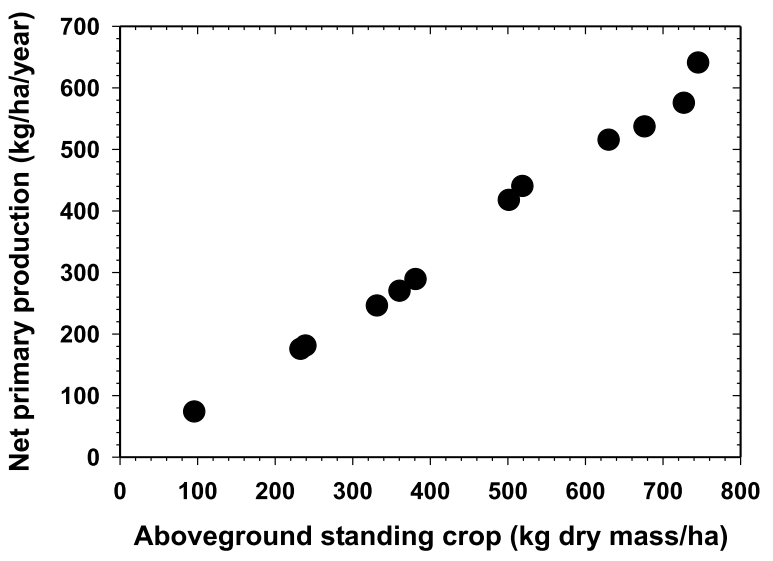

between our caribou and muskox estimates for specific sites and those of Ferguson and Gauthier (1992) for whole-island populations, which is consistent with our belief that our estimates for caribou and muskoxen are valid for the local areas we studied.

\section{Estimating herbivore offtake}

To build a model of the trophic dynamics of the tundra we 
Table 7. Densities of herbivores at the 17 sites sampled by the Swedish Tundra Northwest Expedition of 1999.

\begin{tabular}{|c|c|c|c|c|c|c|c|c|}
\hline \multirow[b]{2}{*}{ Site No. } & \multirow[b]{2}{*}{ Site name } & \multicolumn{2}{|c|}{$\begin{array}{l}\text { Lemmings and } \\
\text { voles }\end{array}$} & \multirow[b]{2}{*}{$\begin{array}{l}\text { Arctic } \\
\text { hare }\end{array}$} & \multirow[b]{2}{*}{ Geese } & \multirow[b]{2}{*}{ Ptarmigan } & \multirow[b]{2}{*}{ Muskox } & \multirow[b]{2}{*}{ Caribou } \\
\hline & & $\begin{array}{l}\text { Winter } \\
\text { nests }\end{array}$ & $\begin{array}{l}\text { Snap } \\
\text { traps }\end{array}$ & & & & & \\
\hline 1 & Ungava Peninsula & 142.6 & 10 & 0 & 1.37 & 0 & 0 & 2.90 \\
\hline 2 & Melville Peninsula & 7.8 & 37 & 0.01 & 0.79 & 0.05 & 0 & 1.15 \\
\hline 3 & Somerset Island & 275.9 & 1 & 0.002 & 0.03 & 0.01 & 0.44 & 0 \\
\hline 4 & Bathurst Island south & 84.2 & 196 & 0.001 & 0.06 & 0.01 & 0.60 & 0.07 \\
\hline 5 & Bathurst Island north & 15.7 & - & 0 & 0.01 & 0 & 0.06 & 0.01 \\
\hline 6 & King William Island & 72.2 & 7 & 0 & 67.34 & 0.002 & 0.12 & 0 \\
\hline 7 & Wollaston Peninsula & 66.9 & 1 & 0.02 & 0.35 & 0 & 0.93 & 1.30 \\
\hline 8 & Amundsen Gulf & $?^{*}$ & 3880 & 0.01 & 0.06 & 0 & 0.18 & 0.17 \\
\hline 9 & Banks Island south & 107.4 & 239 & 0.001 & 0.03 & 0.002 & 1.41 & 0.05 \\
\hline 10 & Ivvavik & $? *$ & 4961 & 0 & 0 & 0 & 0 & 0.05 \\
\hline 11 & Cape Bathurst & 917.2 & 112 & 0 & 0.60 & 0.10 & 0 & 0.22 \\
\hline 12 & Banks Island north & 16.2 & 5 & 0.01 & 0.23 & 0.01 & 4.34 & 0.08 \\
\hline 13 & Melville Island & 27.9 & 27 & 0.02 & 0 & 0.002 & 1.32 & 0.27 \\
\hline 14 & Ellef Ringnes Island & 12.0 & 1 & 0 & 0.001 & 0 & 0 & 0.65 \\
\hline 15 & Ellesmere Island & 33.3 & 1 & 0.0003 & 0.20 & 0.01 & 0 & 0 \\
\hline 16 & Devon Island & 379.9 & 125 & 0.12 & 0.22 & 0.11 & 8.06 & 0.22 \\
\hline 17 & Baffin Island & 161.0 & 27 & 0.07 & 0.17 & 0.09 & 0 & 0 \\
\hline$P / B$ ratio assumed & & & & 3.25 & 2.50 & 5.25 & 0.29 & 0.26 \\
\hline
\end{tabular}

need to be able to estimate the offtake of vegetation by the herbivores. Since we have not measured this directly, we must use literature values to approximate the mass of primary production consumed (see Table 8). We used the field metabolic rate estimates of Nagy (1987) to estimate the energy requirements of all herbivores. We used diet estimates from Batzli and Pitelka (1983) and Bergman (1991) for lemmings and voles and those from Klein and Bay (1991) for the arctic hare. For rock ptarmigan diets we used data compiled by Holder and Montgomerie (1993). For caribou and muskoxen we used an average diet from Parker (1978). We assume that geese eat only grasses and sedges (Hik et al. 1992). We utilize these estimates of herbivore offtake in the ECOPATH model we develop later.

\section{Estimating herbivore production}

To build a model of the trophic dynamics of the tundra we also need to be able to estimate net annual secondary production by the herbivores. We have no direct data on annual production rates of herbivores and we estimated minimum and maximum $P / B$ ratios for herbivores from literature data. Minimum $P / B$ ratios can be estimated from the maximum finite rate of population growth per year observed for a particular species (in the absence of immigration). Maximum $P / B$ ratios can be estimated from litter or clutch sizes (corrected for sex ratio), since in annual breeders there could be no higher rate of production. In our analysis we have used maximum $P / B$ ratios to build the ECOPATH model, and these ratios are given in Table 7. Clearly, lemming populations in the Arctic are highly variable, and we have only a single snapshot of densities at each site. We address this problem in the Discussion.

\section{Predator dynamics}

\section{Problems of estimating the density of wide-ranging predators}

Predators vary dramatically in abundance from year to year in arctic communities as a result of local movements. In our walking and aerial surveys we attempted to obtain an average local density of predators as an instantaneous sample that we could relate to prey numbers. Since predators may not respond instantaneously to changes in prey numbers, there is always the possibility that we have data on transient dynamics rather than on a near-equilibrium situation. The limited data that we have on lemming abundance across the Arctic suggest that lemming populations were declining or low for the year preceding the Swedish Tundra Northwest Expedition of 1999, so we suggest that our estimates of predator abundance are characteristic of the low phase of the lemming cycle rather than an extensive peak.

\section{Abundance of avian and mammalian predators}

Table 9 summarizes our estimates of the abundance of avian and mammalian predators. In total, only 13 breeding dens of arctic foxes were found during our foot surveys, which covered $758 \mathrm{~km}^{2}$. We also observed 12 adult arctic foxes and 5 red foxes, but no red fox breeding attempts. The presence of wolves was noted from tracks and faeces at two sites and the presence of weasels from a few winter nests at six sites. Numbers of avian lemming predators were low at most sites, in association with the general low numbers of rodents. Sites 8 and 10, which had high tundra vole populations, did not have exceptionally high numbers of predators. Long-tailed jaegers that were probable breeders were found at eight sites and parasitic jaegers at six sites. Peregrine 
Table 8. Diets assumed for herbivores (A) and predators (B) in the ECOPATH model, shown as percent consumption of each food category.

\begin{tabular}{|c|c|c|c|c|c|c|}
\hline \multicolumn{7}{|l|}{ (A) Herbivores. } \\
\hline & Mosses & Dryas & Willows & Grasses/sedges & Saxifraga & Herbs \\
\hline Brown lemming & 32.0 & 5.5 & 2.5 & 56.0 & - & 4.0 \\
\hline Collared lemming & 3.0 & 83.0 & 6.0 & 7.0 & - & 1.0 \\
\hline Tundra vole & 13.8 & 3.7 & 2.5 & 76.0 & - & 4.0 \\
\hline Arctic hare & 13.2 & 2.1 & 13.6 & 59.4 & - & 11.7 \\
\hline Geese & - & - & - & 100.0 & - & - \\
\hline Ptarmigan & - & 32.0 & 60.0 & - & 5.0 & 3.0 \\
\hline Insects & - & 40.0 & 40.0 & 20.0 & - & - \\
\hline Caribou & 40.6 & 1.8 & 24.1 & 21.3 & 3.7 & 8.5 \\
\hline$\underline{\text { Muskox }}$ & 8.0 & 3.0 & 25.0 & 57.0 & 2.0 & 5.0 \\
\hline \multicolumn{7}{|l|}{ (b) Predators. } \\
\hline & \multicolumn{6}{|l|}{ Prey eaten } \\
\hline & Lemmings & $\begin{array}{l}\text { Arctic } \\
\text { hare }\end{array}$ & Geese & Ptarmigan & $\begin{array}{l}\text { Small birds, } \\
\text { insects }^{a}\end{array}$ & Carrion \\
\hline Foxes & 80.8 & 6.4 & 6.0 & - & 1.5 & 5.3 \\
\hline Ermine & 75.0 & 10.0 & - & 5.0 & 5.0 & 5.0 \\
\hline \multicolumn{7}{|l|}{ Gulls } \\
\hline High Arctic & 40.0 & 20.0 & 10.0 & 5.0 & 15.0 & 10.0 \\
\hline Low Arctic & 10.0 & 20.0 & 35.0 & 10.0 & 15.0 & 10.0 \\
\hline \multicolumn{7}{|l|}{ Raven } \\
\hline High Arctic & 20.0 & 20.0 & 10.0 & 5.0 & 30.0 & 15.0 \\
\hline Low Arctic & 10.0 & 20.0 & 15.0 & 10.0 & 30.0 & 15.0 \\
\hline \multicolumn{7}{|l|}{ Long-tailed jaeger } \\
\hline High Arctic & 90.0 & - & - & - & 10.0 & - \\
\hline Low Arctic & 46.0 & - & - & - & 54.0 & - \\
\hline \multicolumn{7}{|l|}{ Parasitic jaeger } \\
\hline High Arctic & 24.5 & - & - & - & 75.5 & - \\
\hline Low Arctic & 10.0 & - & - & - & 90.0 & - \\
\hline Rough-legged hawk & 90.0 & 2.0 & 2.0 & 3.0 & 3.0 & - \\
\hline Peregrine falcon & 5.0 & - & 15.0 & - & 80.0 & - \\
\hline Gyrfalcon & 0.5 & 10.0 & 0.1 & 73.0 & 16.4 & - \\
\hline Snowy owl ${ }^{b}$ & 99.0 & - & - & - & 1.0 & - \\
\hline
\end{tabular}

Note: Wolf diets are not given. Wolves are assumed to eat caribou and muskoxen in proportion to their relative abundance at each site.

${ }^{a}$ These species were not quantified in the ECOPATH model.

${ }^{b}$ Snowy owls also eat ermine $(0.1 \%$ of the diet $)$.

falcons were seen at most sites, while gyrfalcons were rare. The aerial surveys gave the same picture as the walking surveys but over larger areas. They also showed that lemming trapping and walking surveys were generally carried out in the most productive habitat at each site.

We estimated the composition of the diets of arctic and red foxes from our studies. In arctic fox scats we identified brown lemmings, collared lemmings, arctic hares, ducks and geese, ptarmigan, waders, passerines, insects, and plant material. Only 1 scat out of 508 contained fish bones. Neither arctic ground squirrel nor vole (Microtus spp., Clethrionomys spp.) remains were found in arctic fox scats, but no fox scats were found at site 8 or 10 , where these species might have been taken by foxes. Less than $2 \%$ of fox scats contained material of marine origin, confirming that for these predators the food chain was largely terrestrial.

We estimated diets of other predators from the literature. We used Reid et al. (1997) for diets of gulls, and assumed that diet composition for ravens was the same as for gulls. For rough-legged hawks and snowy owls we used the diet data of Wiklund et al. (1998) and Reid et al. (1997). For jaegers we used the diet data in Maher (1974). For gyrfalcons we used the diet data in Poole and Boag (1988). For peregrine falcons we assumed a diet of $80 \%$ small birds, 5\% lemmings, and $15 \%$ geese. For ermine we could find no diet data for arctic sites and we assumed a diet of $70 \%$ lemmings and voles, $10 \%$ birds, and $20 \%$ carrion. Diet data used in the ECOPATH model that follows are summarized in Table 8. Note that we used the same diets for each site, a problem we return to in the discussion.

\section{Synthesis and modeling}

\section{Food webs}

The summer food web on the tundra is relatively simple but varies from site to site (Fig. 2, Table 6). Among the birds 
Table 9. Densities of predatory birds and mammals at the 17 sites sampled by the Swedish Tundra Northwest Expedition in 1999.

\begin{tabular}{|c|c|c|c|c|c|c|c|c|c|c|c|c|}
\hline $\begin{array}{l}\text { Site } \\
\text { No. }\end{array}$ & Site name & $\begin{array}{l}\text { Area* } \\
\left(\mathrm{km}^{2}\right)\end{array}$ & $\begin{array}{l}\text { Arctic } \\
\text { and red } \\
\text { foxes }\end{array}$ & Ermine & $\begin{array}{l}\text { Long- } \\
\text { tailed } \\
\text { jaeger }\end{array}$ & $\begin{array}{l}\text { Parasitic } \\
\text { jaeger }\end{array}$ & Gulls & Gyrfalcon & $\begin{array}{l}\text { Peregrine } \\
\text { falcon }\end{array}$ & $\begin{array}{l}\text { Rough- } \\
\text { legged } \\
\text { hawk }\end{array}$ & $\begin{array}{l}\text { Snowy } \\
\text { owl }\end{array}$ & Raven \\
\hline 1 & Ungava Peninsula & 14.3 & 0.14 & 0.2 & 0 & 0 & 0 & 0 & 0.07 & 0 & 0 & 0 \\
\hline 2 & Melville Peninsula & 34.0 & 0.09 & 0 & 0.18 & 0 & 0.09 & 0 & 0 & 0 & 0 & 0.03 \\
\hline 3 & Somerset Island & 77.7 & 0 & 0.02 & 0 & 0 & 0.10 & 0 & 0.01 & 0 & 0 & 0.08 \\
\hline 4 & Bathurst Island south & 57.0 & 0.07 & 0 & 0.42 & 0 & 0.39 & 0 & 0 & 0 & 0.09 & 0 \\
\hline 7 & Wollaston Peninsula & 56.0 & 0.02 & 0.02 & 0.07 & 0.04 & 0.13 & 0 & 0.04 & 0.04 & 0 & 0.04 \\
\hline 8 & Amundsen Gulf & 34.0 & 0 & 0.02 & 0 & 0 & 0.06 & 0 & 0.12 & 0.12 & 0 & 0.24 \\
\hline 9 & Banks Island south & 50.5 & 0.08 & 0.02 & 0.18 & 0.04 & 0.28 & 0 & 0.02 & 0.12 & 0 & 0 \\
\hline 10 & Ivvavik & 26.0 & 0.04 & 0 & 0.35 & 0.04 & 0.15 & 0.08 & 0.04 & 0.12 & 0.08 & 0.08 \\
\hline 11 & Cape Bathurst & 29.0 & 0.10 & 0 & 0.03 & 0.24 & 0.90 & 0 & 0.07 & 0 & 0 & 0 \\
\hline 12 & Banks Island north & 25.0 & 0.16 & 0 & 0 & 0 & 0.20 & 0 & 0.08 & 0.20 & 0 & 0 \\
\hline 16 & Devon Island & 42.0 & 0.02 & 0.02 & 0 & 0 & 0.43 & 0.05 & 0.05 & 0.05 & 0.07 & 0 \\
\hline 17 & Baffin Island & 49.0 & 0.02 & 0 & 0 & 0 & 0.08 & 0 & 0 & 0 & 0 & 0.06 \\
\hline
\end{tabular}

Note: Densities are given as the number of individuals per square kilometre.

*The size of each area surveyed during walking.

and mammals are 17 species of predators (including omnivores) and 10 species of herbivores. Many of the birds and some of the mammals are seasonal migrants, so the food web changes dramatically from summer to winter.

We can detect no relationship between standing crop of vascular plants and species richness of herbivores $(r=-0.16$, $n=12$ ), but there is a positive relationship between standing crop of vascular plants and species richness of predators $(r=$ $0.73)$. Figure 5 illustrates this trend, showing more predator species in the richer, Low-Arctic sites in the western Arctic. Since net primary productivity is related to standing crop for arctic sites, predator species richness is also correlated with net primary production of vascular plants $(r=0.75, n=12)$.

\section{What becomes of terrestrial production in the Canadian Arctic?}

We can summarize our results in an ECOPATH model (Christensen and Pauly 1992; Pauly et al. 2000, http:// www.ecopath.org/). The ECOPATH model is a relatively simple approach to analysing ecosystem trophic mass balance using the basic equation of Polovina (1984):

$$
B_{r}\left(\frac{P_{r}}{B_{r}}\right) \mathrm{EE}_{r}+I_{r}=\sum_{c}\left[B_{c}\left(\frac{Q_{r}}{B_{c}}\right) d_{r c}\right]+\Delta B_{r}+E_{r}
$$

where $B$ is biomass, $P$ is production, EE is ecotrophic efficiency, $I$ is immigration, $Q$ is consumption, $d$ is diet composition, $E$ is emigration, and the subscripts $r$ and $c$ refer to parameters of the resource (species or species-group) and each consumer (species or species-group), respectively.

The basic mass-balance equation equates production and consumption of each taxon, and for our data can be applied to a time period when standing biomass is assumed to be invariant. In this case immigration and emigration rates are 0 and there is no change in biomass $(\Delta B)$, so the basic equation simplifies to
Fig. 5. Relationship of species richness of predators and standing crop of vascular-plant vegetation at sites 6-17 of the Swedish Tundra Northwest Expedition of 1999 (functional regression line: number of predator species $=0.0104$ standing crop $+1.0243(\mathrm{SE}$ of slope $=0.00227, r=0.73, n=12)$ ).

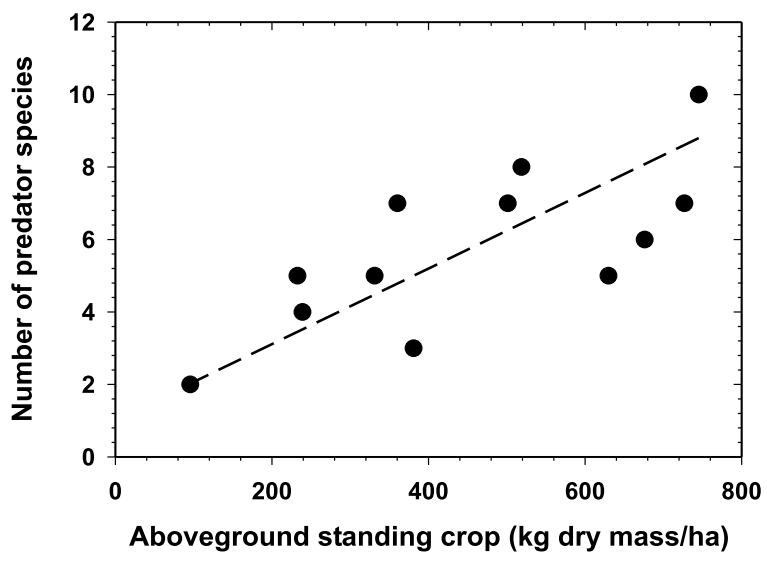

[5]

$$
B_{r}\left(\frac{P_{r}}{B_{r}}\right) \mathrm{EE}_{r}=\sum_{c}\left[B_{c}\left(\frac{Q_{r}}{B_{c}}\right) d_{r c}\right]
$$

In our use of this model, $I, E$, and $\Delta B$ are assumed to be 0 , while $B, P / B, Q / B$, and diet composition are entered into the model for each taxon and EE is calculated via matrixinversion algorithms. The only parameter in this equation that is difficult to comprehend is EE, which is defined as that part of production which is consumed by the next trophic level. For each species-group of plants, EE is that fraction of production which is consumed by herbivores. For each herbivore, EE is that fraction of herbivore production which is consumed by predators. 
We used the ECOPATH model to answer three questions: (1) What fraction of net primary production is consumed by herbivores in arctic ecosystems? (2) What fraction of herbivore production is consumed by predators in these communities? (3) Does the answer to either of these questions depend on the phytomass or productivity of the plant community as we move from Low-Arctic sites to High-Arctic sites?

Table 10 gives EE estimates for each species-group of plants and herbivores at each site. The first point to note is that EEs should never be above 1 in an equilibrial system, since this implies that more is being eaten than is being produced. Four conclusions are supported by these data. First, EEs of plants are uniformly low, and, on average, about $13 \%$ of plant production flows into the herbivore trophic level (Fig. 6) at the low densities of small mammals that characterized most of our sites. There are three cases in which plant groups at a particular site have excessive EEs. Second, EEs of small herbivores are uniformly high. One-third of the EEs of small herbivores exceed 3, an impossible situation if the system is assumed to be in equilibrium. To analyse these EEs, we decided to truncate all values above 1 to the theoretical maximum of 1.0, assuming that our diet or abundance estimates are incorrect for the particular site. If we do this for small herbivores, the EEs of small herbivores average $70 \% .^{3}$ Of the small herbivores, lemmings have the lowest average EE, 29\%. Third, the EEs of large herbivores (caribou, muskox) are low, averaging 9\%. Since wolves are the major predator of caribou and muskoxen, this implies that predation at the present time removes only a small portion of the net production of these large mammals. Fourth, there is no pattern in these efficiencies with respect to Low-Arctic or High-Arctic sites. There is no correlation of EEs with standing crop of vegetation either with all plant groups considered individually ( $r=0.04, n=68)$ or with the average EE for all plant groups at each site $(r=0.10, n=12)$. Similarly, there is no correlation of EEs with net primary production $(r=$ 0.07, $n=68$, and $r=0.14, n=12$ ) (Fig. 7).

\section{Discussion}

In this study we have attempted to achieve a broad-brush summary of the trophic dynamics of the terrestrial tundra areas of northern Canada. There are severe limitations to our data, since we could spend very little time at each site, and we have substituted information on the large spatial variance among sites for intensive work at one site. There has been no earlier attempt to bring together data on trophic dynamics on this scale. Our analysis depends heavily on published assessments of the relationship between standing crop of vegetation and net primary productivity. We have only limited data with which to compare estimates of herbivore and predator abundance at our sites, but by the use of faecal-pellet surveys we hope we have achieved an average estimate of population density for the rarer species.

Our analysis suffers from two problems. First, we cannot place confidence limits on our EE estimates for each site. We do have replication among the sites and among the forage groups and herbivores, and this allows us to estimate
Fig. 6. Ecotrophic efficiencies (EEs), with $95 \%$ confidence limits, for plants, small herbivores, and large herbivores from the Canadian Arctic. Plant EEs average 0.13, while small-herbivore EEs average 0.70. Caribou and muskoxen show low EEs, averaging 0.09 , suggesting that little of their net production flows into the predator trophic level. In theory, EEs should never exceed 1.0, since this implies that more is consumed than is produced.

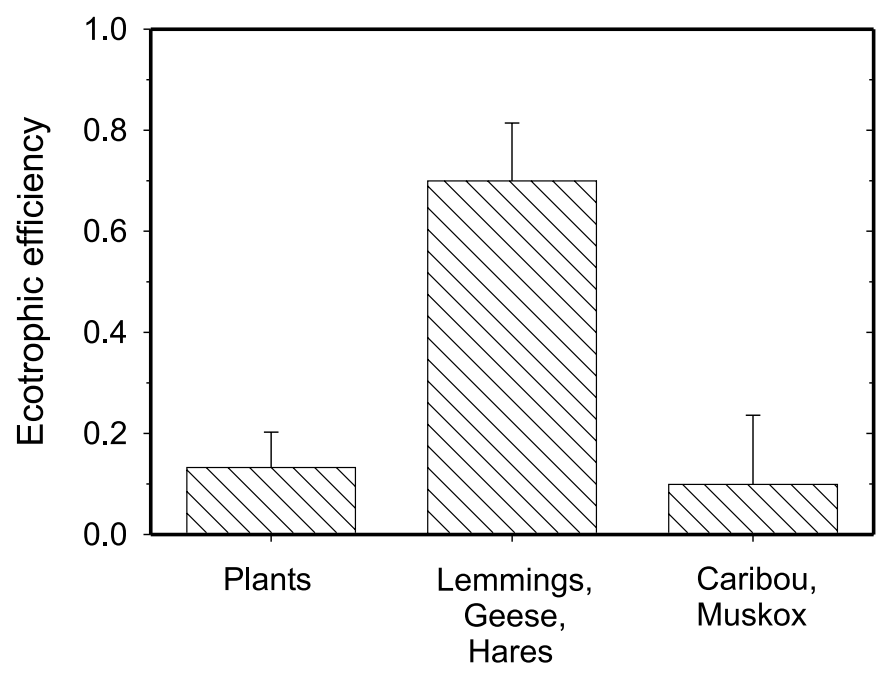

confidence limits for EEs among sites (Fig. 6). Our estimates of plant biomass and herbivore density were obtained using methods that permit us to estimate the confidence limits of individual estimates. Predator densities from ground surveys are point estimates without confidence limits, and we see no simple way of generating confidence limits on predator numbers without making unwarranted assumptions about detectability. We can defend our inability to specify probable errors in our estimates of EEs at each site by suggesting that they can be obtained only by a replicated study at these sites in the future.

Another major constraint on our data, assuming that our estimates are reasonably accurate, is that we have a snapshot in time of an ecosystem that varies dramatically from year to year, largely as a reflection of the rise and fall of the lemming cycle but also because of changing numbers of muskoxen and caribou. Our data are probably typical of a relatively low year in lemming numbers, and if we had our choice, we would repeat these studies in a year when many lemming populations were near peak numbers. Predator numbers in general were low at all sites. At a typical arctic site, avian predators come through in early spring to assess prey abundance, then depart quickly if rodent numbers are low. Our sites were assessed in mid to late summer so that we avoided this pulse of predator numbers. Again this problem can be addressed only by future replicated studies at these sites.

Because of logistics, all of the sites we visited were within $10 \mathrm{~km}$ of the coast. We do not know if this coastal bias affects our conclusions. There is only a slight overlap between marine and terrestrial food webs in the Arctic, and our data on fox diets indicate that we were sampling the terrestrial system with little input from marine food webs. It is unlikely that we can ever randomly sample the terrestrial

\footnotetext{
${ }^{3}$ If we are more liberal and truncate all EEs above 3, the average EE is 0.88 , so this conclusion is robust.
} 


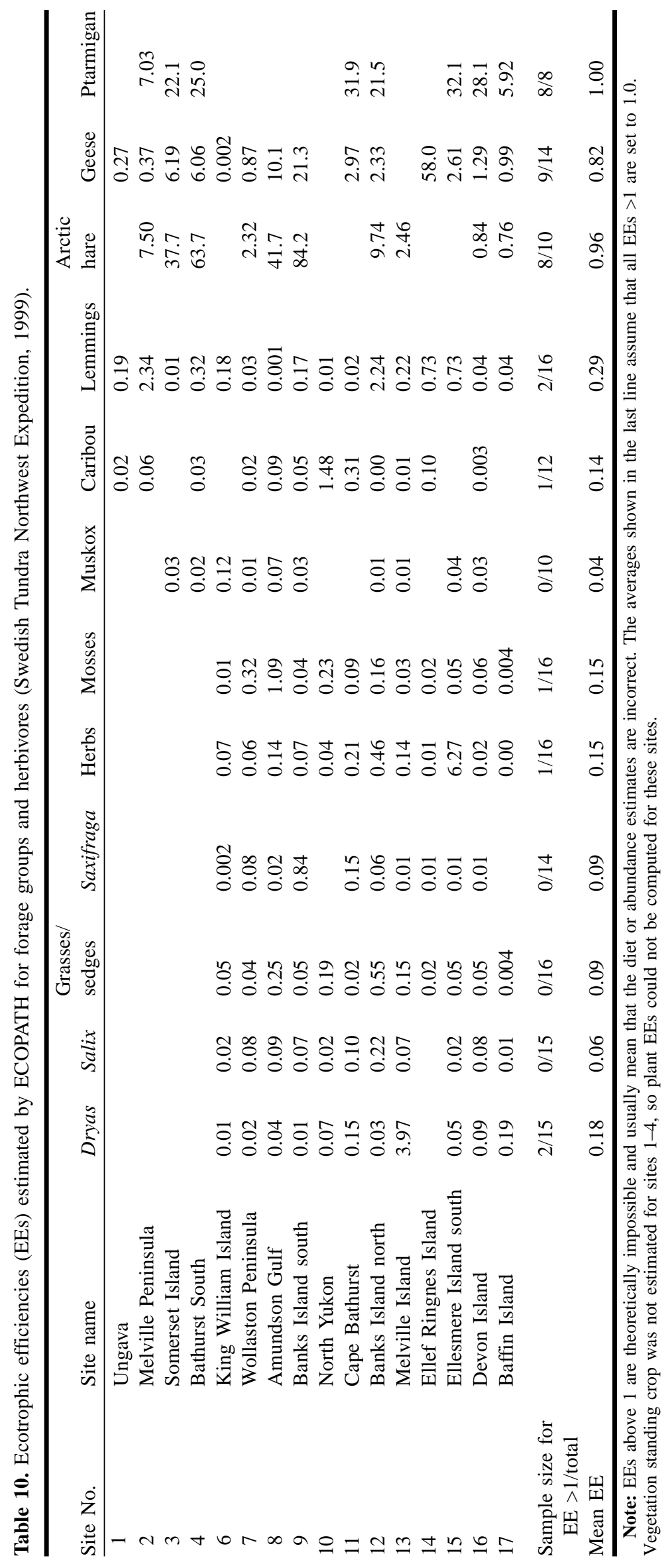


Fig. 7. Relationship of ecotrophic efficiency (EE) of plants and net primary productivity of vascular plants at sites 6-17 of the Swedish Tundra Northwest Expedition of 1999. The EE of plants is the estimated fraction of net plant production that is consumed by herbivores, and shows no relationship to net primary production. The arrow indicates the mean EE, $13 \%$.

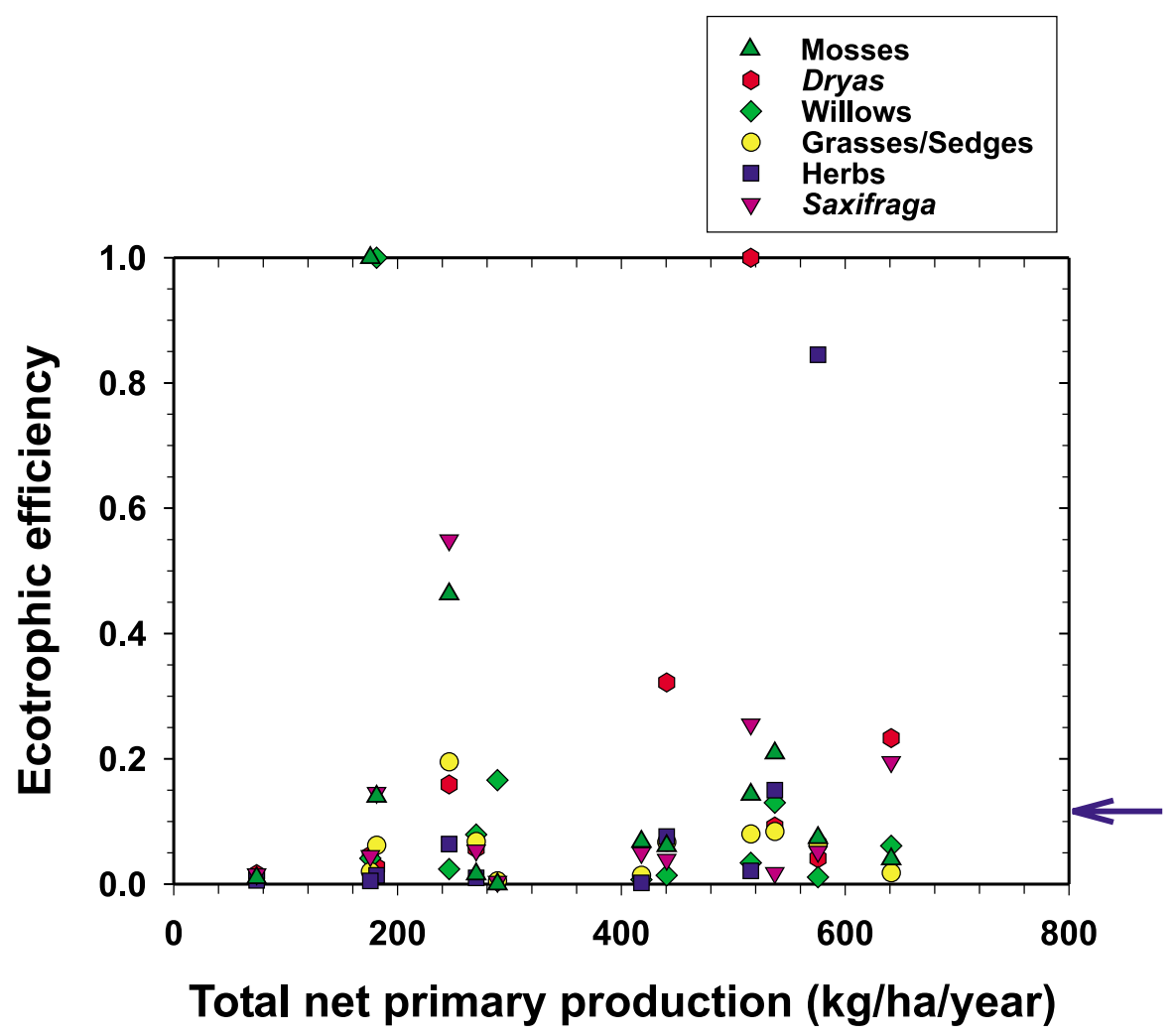

ecosystems of the Arctic, and future studies will have to test whether our conclusions are only applicable to coastal sites.

Our estimated EEs are robust to two potential problems. At sites where herbivores have eaten a substantial amount of the standing crop of plants, we will underestimate net primary production because our cover estimates will be biased low. This will inflate our estimated EEs for plants, but a correction would only lower our already very low estimates. The only evidence we have that a correction is not required is that we recorded only $3.3 \%$ of ramets of Carex and Eriophorum with grazing marks on them, which suggests a relatively low grazing pressure at our sites. Second, if grazed forage has the potential to compensate for the biomass lost to grazers (Bråthen and Odasz-Albrigtsen 2000), our estimated net primary production will be biased low, thereby again inflating EEs for plants. In both these cases our conclusions about low EEs for plants are robust to potential causes of error.

We have summarized our results in an ECOPATH model of trophic dynamics. ECOPATH has been widely used in fisheries research, but there are almost no applications of this model to terrestrial ecosystems (Ruesink et al. 2002). We have reached two tentative conclusions from our modeling of trophic flows at these arctic sites. The terrestrial ecosystem of the Canadian Arctic seems to be largely a topdown system for the small and mid-sized herbivores. Predators in general consume all of the production of the smallherbivore community, while herbivores in general consume only a small fraction of the plant production. The exceptions to these generalizations are the EEs muskoxen and caribou, which are low. Relatively little of the net production of muskoxen and caribou in the Canadian Arctic at the present time seems to flow into the predators. There is a longstanding controversy in wildlife management about whether these large mammals are harvest-limited, weather-limited, food-limited, or predator-limited (Van Ballenberghe 1985; Bergerud and Elliott 1986; Bergerud and Ballard 1988; Messier 1995; Caughley and Gunn 1993; Ballard et al. 1997; Gunn et al. 2000). Our results are inconsistent with both the food-limitation hypothesis and the predator-limitation hypothesis, since plant offtake by herbivores was low and herbivore offtake by predators was also low. We agree with Gunn et al. (2000) that both weather factors and human harvest are critical for these large mammals in the Canadian Arctic.

We developed our best estimates of the parameters in the ECOPATH model, and did not then tinker with the results. EEs should never be above 1.0 in an equilibrial system, and it is critical to look into why we obtained many above 1.0, particularly for the herbivores. Four factors in our data could cause EEs to be above 1.0. First, the diet data may be in error. Diets have been generalized across the whole Canadian Arctic for most predators. We used slightly different diets for wolves, gulls, ravens, and jaegers for the Low-Arctic and High-Arctic sites, but diets were not site-specific. This means that when we observed a low density of, for example, ptarmigan at a particular site, we kept the diets of gyrfalcons and rough-legged hawks at that site the same, producing a high EE for ptarmigan at that site. A similar bias will result if the composition of a predator's diet is a result of scavenging. Second, if the densities of herbivores are underestimated or the densities of predators overestimated, the resulting EEs 
for the herbivores will be too high. Third, if average body masses for the species are incorrect, the same problem will arise. And finally, if the $P / B$ ratios are too low for herbivores, the EEs will be too high.

We cannot evaluate the exact contribution of each of these four factors to the unrealistic EE values in our study. Average body masses are most likely reasonably reliable, so we do not think that the third factor is a key one. We have deliberately tried to use $P / B$ ratios for herbivores estimated from clutch or litter sizes, so they should be close to maximum values, and thus we do not think that low $P / B$ ratios for herbivores are the main reason for the excessive EEs for herbivores. Densities of herbivores and predators have a significant margin of error, but unless they are off by an order of magnitude they are probably not the main source of error. We thus zero in on diets as the main reason why EEs are overestimated. We suggest that site-specific diet data would reduce the high EEs in Table 10, and this hypothesis needs to be tested by further research. If so, it is probable that the high EEs in our analysis indicate true EEs to be approximately 1.0 .

Lemming EEs averaged $29 \%$ in our data for populations that were low to slightly increasing. If we hypothetically increase the $P / B$ ratio for lemmings from 13.3 to 98 , as would occur in a rapidly increasing population (Wilson et al. 1999), the EEs fall to about 5\%, which suggests no limitation by predation in this phase of the cycle. If we reduce the $P / B$ ratio for lemmings to a low value (2.1) that would occur in a cyclic decline, the EEs for lemmings increase to over $62 \%$, indicating a strong possibility of predator impacts during the decline phase (Korpimäki and Norrdahl 1998; Wilson et al. 1999). If lemming predators increase with a time lag, predator numbers after a lemming peak will not be in an equilibrium and their impact could be significantly higher than we have observed, which would further increase the EE value during the decline phase of the cycle. A similar scenario was modeled with data from cyclic snowshoe hare populations by Ruesink et al. (2002).

Our results are broad-brush ones. The tundra community may appear to be a top-down system for small herbivores because the available food plants are of poor quality (White 1993). This hypothesis needs more research, although we note that it has been tested and rejected for lemmings by Batzli et al. (1980). Alternatively, severe weather might limit herbivore numbers, so that again the system would appear to be top-down because herbivores are well below their carrying capacity (Caughley and Gunn 1993). Caribou numbers in tundra areas can fluctuate dramatically over long time scales (Morneau and Payette 2000), further suggesting the non-equilibrium nature of tundra communities.

In conclusion, we recognize that our analysis of the trophic dynamics of the Canadian Arctic is coarse and timespecific, but we believe that it is a start to looking at the whole terrestrial system of the Arctic. Community ecology has been hindered by the lack of an arithmetic for community interactions, and ECOPATH is an important attempt to provide a quantitative framework for trophic interactions. It is an assumption of our analysis that high EEs indicate topdown control in ecosystems. Many assumptions that we had to make need to be tested by further work in the north. We also recognize that there are linkages between marine and terrestrial ecosystems in the Arctic, but we are not in a position to evaluate the relative contributions of marine production and terrestrial dynamics.

In the face of global environmental changes, ecological monitoring of sensitive areas is essential. We need to establish baselines for northern Canada in order to evaluate future ecological changes in this region. It is important not only that we obtain data that elucidate ecological details of individual species but also that we acquire a more holistic understanding of how these ecosystems operate. Although much remains to be done to resolve these broad issues, we hope that this study adds some understanding of the trophic dynamics of arctic regions.

\section{Acknowledgements}

We thank the Swedish Polar Secretariat for financial support of the Swedish Tundra Northwest Expedition of 1999, and the crew of the Canadian Coast Guard icebreaker Louis $S$. St-Laurent, who made the expedition enjoyable. We thank all the members of the Expedition for their helpful discussions and interactions. We thank Jennifer Ruesink and Karen Hodges for their help with developing the ECOPATH model. The material included in the ECOPATH model is available from the senior author and the details of the data are also available in an Excel file at http://www.zoology.ubc.ca/ $\sim$ krebs/ in the area labeled Swedish Tundra Northwest 99 Expedition.

\section{References}

Angerbjörn, A., Tannerfeldt, M., and Erlinge, S. 1999. Predatorprey relations: arctic foxes and lemmings. J. Anim. Ecol. 68: 34-49.

Ballard, W.B., Ayres, L.A., Krausman, P.R., Reed, D.J., and Fancy, S.G. 1997. Ecology of wolves in relation to a migratory caribou herd in northwest Alaska. Wildl. Monogr. No. 61. pp. 1-45.

Banfield, A.W.F. 1974. The mammals of Canada. University of Toronto Press, Toronto.

Batzli, G.O., and Pitelka, F.A. 1983. Nutritional ecology of microtine rodents: food habits of lemmings near Barrow, Alaska. J. Mammal. 64: 648-655.

Batzli, G.O., White, R.G., Maclean, S.F., Pitelka, F.A., and Collier, B.D. 1980. The herbivore-based trophic system. In An arctic ecosystem. Edited by J. Brown, P.C. Miller, L.L. Tiezen, and F.L. Bunnell. Dowden, Hutchinson, and Ross, Stroudsburg, Pa. pp. 335-410.

Bergerud, A.T., and Ballard, W.B. 1988. Wolf predation on caribou: the Nelchina herd case history, a different interpretation. J. Wildl. Manag. 52: 344-357.

Bergerud, A.T., and Elliot, J.P. 1986. Dynamics of caribou and wolves in northern British Columbia. Can. J. Zool. 64: 15151529.

Bergman, C.M. 1991. An examination of the diets and demographies of the collared lemming (Dicrostonyx kilangmiutak) and tundra vole (Microtus oeconomus) at Pearce Point, Northwest Territories, and possible consequences for competition. B.Sc. thesis, University of British Columbia, Vancouver.

Bliss, L.C. 1977. General summary: Truelove Lowland ecosytem. In Truelove Lowland, Devon Island, Canada: a high arctic ecosystem. Edited by L.C. Bliss. University of Alberta Press, Edmonton. pp. 657-675. 
Bliss, L.C., and Svoboda, J. 1984. Plant communities and plant production in the western Queen Elizabeth Islands. Holarct. Ecol. 7: 325-344.

Bliss, L.C., Svoboda, J., and Bliss, D.I. 1984. Polar deserts, their plant cover and plant production in the Canadian high arctic. Holarct. Ecol. 7: 305-324.

Brom, T.G. 1986. Microscopic identification of feathers and feather fragments of Palearctic birds. Bijdr. Dierkd. 56: 181-204.

Bråthen, K.A., and Odasz-Albrigtsen, A.M. 2000. Tolerance of the arctic graminoid Luzula arcuata ssp. confusa to simulated grazing in two nitrogen environments. Can. J. Bot. 78: 1108-1113.

Buckland, S.T., Anderson, D.R., Burnham, K.P., and Laake, J.L. 1993. Distance sampling: estimating abundance of biological populations. Chapman \& Hall, London.

Caughley, G., and Gunn, A. 1993. Dynamics of large herbivores in deserts: kangaroos and caribou. Oikos, 67: 47-55.

Chase, J.M. 2000. Are there real differences among aquatic and terrestrial food webs? Trends Ecol. Evol. 15: 408-412.

Chiarucci, A., Wilson, J.B., Anderson, B.J., and De Dominicis, V. 1999. Cover versus biomass as an estimate of species abundance: does it make a difference to the conclusions? J. Veg. Sci. 10: $35-52$.

Christensen, V., and Pauly, D. 1992. ECOPATH II - a software for balancing steady-state ecosystem models and calculating network characteristics. Ecol. Model. 61: 169-185.

Cyr, H., and Pace, M.L. 1993. Magnitude and patterns of herbivory in aquatic and terrestrial ecosystems. Nature (London), 361: $148-150$.

Day, M.G. 1996. Identification of hair and feather remains in the gut and faeces of stoats and weasels. J. Zool. (Lond.), 148: 201-217.

Dunning, J.B. (Editor). 1993. CRC handbook of avian body masses. CRC Press, Boca Raton, Fla.

Fedorov, V.B., Fredga, K., and Jarrell, G.H. 1999. Mitochondrial DNA variation and the evolutionary history of chromosome races of collared lemmings (Dicrostonyx) in the Eurasian Arctic. J. Evol. Biol. 12: 134-145.

Ferguson, M.A.D., and Gauthier, L. 1992. Status and trends of Rangifer tarandus and Ovibos moschatus populations in Canada. Rangifer, 12: 127-141.

Flux, J.E.C. 1970. Life history of the mountain hare (Lepus timidus scoticus) in north-east Scotland. J. Zool. (1965-1984), 161: 75-123.

Gunn, A., Miller, F.L., and Nishi, J. 2000. Status of endangered and threatened caribou on Canada's arctic islands. Rangifer Spec. Issue No. 12. pp. 39-50.

Hik, D.S., Jefferies, R.L., and Sinclair, A.R.E. 1992. Foraging by geese, isostatic uplift and asymmetry in the development of saltmarsh plant communities. J. Ecol. 80: 395-406.

Höglund, N.H. 1980. Studies on the winter ecology of the willow grouse (Lagopus lagopus lagopus L.). Swed. Wildl. Res. Viltrevy, 11: $247-270$.

Holder, K., and Montgomerie, R. 1993. Rock ptarmigan Lagopus mutus. In The birds of North America. Edited by A. Poole and F. Gill. The Academy of Natural Sciences, Philadelphia. pp. 1-24.

Klein, D.R., and Bay, C. 1991. Diet selection by vertebrate herbivores in the high arctic of Greenland. Holarct. Ecol. 14: 152-155.

Klein, D.R., and Bay, C. 1994. Resource partitioning by mammalian herbivores in the high Arctic. Oecologia (Berlin), 97: 439-450.

Komárková, V., and Webber, P.J. 1980. Two low arctic vegetation maps near Atkasook, Alaska. Arct. Alp. Res. 12: 447-472.

Korpimäki, E., and Norrdahl, K. 1998. Experimental reduction of predators reverses the crash phase of small-rodent cycles. Ecology, 79: 2448-2455.
Lockie, J.D. 1959. The estimation on the food of foxes. J. Wildl. Manag. 23: 224-227.

Maher, W.J. 1974. Ecology of pomarine, parasitic, and long-tailed jaegers in northern Alaska. Cooper Ornithol. Soc. 37: 1-148.

Messier, F. 1995. On the functional and numerical responses of wolves to changing prey density. In Ecology and Conservation of Wolves in a Changing World: Proceedings of the 2nd North American Symposium On Wolves, Edmonton, Alberta, August 1992. Edited by L.N. Carbyn, S.H. Fritts, and D.R. Seip. Canadian Circumpolar Institute, University of Alberta, Edmonton.

Morneau, C., and Payette, S. 2000. Long-term fluctuations of a caribou population revealed by tree-ring data. Can. J. Zool. 78: 1784-1790.

Muc, M. 1977. Ecology and primary production of sedge-moss meadow communities, Truelove Lowland. In Truelove Lowland, Devon Island, Canada: a high arctic ecosystem. Edited by L.C. Bliss. University of Alberta Press, Edmonton. pp. 157-184.

Murray, D.F. 1994. Floristics, systematics, and the study of arctic vegetation - a commentary. J. Veg. Sci. 5: 777-780.

Nagy, K.A. 1987. Field metabolic rate and food requirement scaling in mammals and birds. Ecol. Monogr. 57: 111-128.

Neff, D.J. 1968. The pellet-group count technique for big game trend, census, and distribution: a review. J. Wildl. Manag. 32: 597-614.

Oksanen, T., Schneider, M., Rammul, U., and Hambäck, P. 1999. Population fluctuations of voles in north Fennoscandian tundra: contrasting dynamics in adjacent areas with different habitat composition. Oikos, 86: 463-478.

Parker, G.R. 1975. An investigation of caribou range on Southampton Island, NWT. Can. Wildl. Serv. Rep. Ser. 33. pp. 1-82.

Parker, G.R. 1978. The diets of muskoxen and Peary caribou on some islands in the Canadian High Arctic. Can. Wildl. Serv. Occas. Pap. No. 35. pp. 1-19.

Pauly, D., Christensen, V., and Walters, C. 2000. ECOPATH, ECOSIM, and ECOSPACE as tools for evaluating ecosystem impact of fisheries. Int. Counc. Explor. Sea J. Mar. Sci. 57: 697-706.

Polovina, J.J. 1984. Model of a coral reef ecosystems I. The ECOPATH model and its application to French Frigate Shoals. Coral Reefs, 3: 1-11.

Poole, K.G., and Boag, D.A. 1988. Ecology of gyrfalcons, Falco rusticolus, in the central Canadian arctic: diet and feeding behaviour. Can. J. Zool. 66: 334-344.

Power, M.E. 1992. Top-down and bottom-up forces in food webs: do plants have primacy? Ecology, 73: 733-746.

Reid, D.G., Krebs, C.J., and Kenney, A.J. 1997. Patterns of predation on noncyclic lemmings. Ecol. Monogr. 67: 89-108.

Röttgermann, M., Steinlein, T., Beyschlag, W., and Dietz, H. 2000. Linear relationships between aboveground biomass and plant cover in low open herbaceous vegetation. J. Veg. Sci. 11: 145-148.

Ruesink, J.L., Hodges, K.E., and Krebs, C.J. 2002. Mass-balance analyses of boreal forest population cycles: merging demographic and ecosystem approaches. Ecosystems, 5: 138-158.

Shaver, G.R., and Chapin, F.S.I. 1991. Production:biomass relationships and element cycling in contrasting arctic vegetation types. Ecol. Monogr. 61: 1-31.

Svoboda, J. 1977. Ecology and primary production of raised beach communities, Truelove Lowland. In Truelove Lowland, Devon Island, Canada: a high arctic ecosystem. Edited by L.C. Bliss. University of Alberta Press, Edmonton. pp. 185-216.

Tener, J.S. 1965. Muskoxen in Canada. Department of Northern Affairs and Natural Resources, Ottawa, Ont.

Thomas, L., Laake, J.L., Derry, J.F., Buckland, S.T., Borchers, D.L., Anderson, D.R., Burnham, K.P., Strindberg, S., Hedley, S.L., 
Burt, M.L., Marques, F., Pollard, J.H., and Fewster, R.M. 1998. Distance 3.5. Research Unit for Wildlife Population Assessment, University of St. Andrews, St. Andrews, U.K.

Van Ballenberghe, V. 1985. Wolf predation on caribou: the Nelchina herd case history. J. Wildl. Manag. 49: 711-720.

Van der Wal, R., and Loonen, M.J.J.E. 1998. Goose droppings as food for reindeer. Can. J. Zool. 76: 1117-1122.

Van Zyll De Jong, C.G., and Carbyn, L.N. 1999. COSEWIC status report on the gray wolf (Canis lupus) in Canada. Committee on the Status of Endangered Wildlife in Canada, Ottawa, Ont. pp. 1-44.

Vitt, D.H., and Pakarinen, P. 1977. The bryophyte vegetation, production, and organic components of Truelove Lowlands. In Truelove Lowland, Devon Island, Canada: a high arctic ecosystem. Edited by L.C. Bliss. University of Alberta Press, Edmonton. pp. 225-244.

Webber, P.J. 1978. Spatial and temporal variation of the vegetation and its production, Barrow, Alaska. In Vegetation and production ecology of an Alaskan Arctic tundra. Edited by L.L. Tieszen. Springer-Verlag, New York. pp. 37-112.

Wein, R.W., and Bliss, L.C. 1974. Primary production in arctic cottongrass tussock tundra communities. Arct. Alp. Res. 6: 261-274.

White, T.C.R. 1993. The inadequate environment: nitrogen and the abundance of animals. Springer-Verlag, New York.

Wielgolaski, F.E., Bliss, L.C., Svoboda, J., and Doyle, G. 1981. Primary production of tundra. In Tundra ecosystems: a comparative analysis. Edited by L.C. Bliss, O.W. Heal, and J.J. Moore. Cambridge University Press, Cambridge. pp. 187-225.

Wiklund, C., Kjellen, N., and Isakson, E. 1998. Mechanisms determining the spatial distribution of microtine predators on the arctic tundra. J. Anim. Ecol. 67: 91-98.

Wilson, D., Krebs, C.J., and Sinclair, A.R.E. 1999. Limitation of collared lemming populations during a population cycle. Oikos, 87: 382-398. 